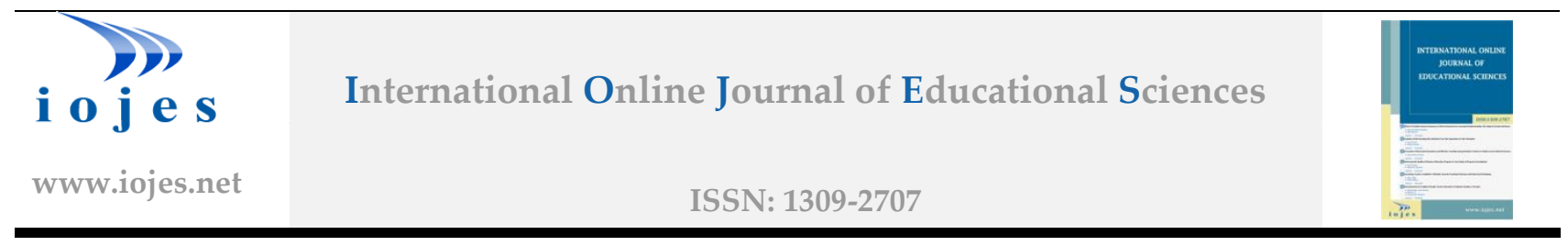

\title{
The Views of Social Studies Teachers on Historical Empathy
}

\author{
Research Article
}

\section{Ummuhan ONER ${ }^{1}$, Muserref Kubra KINACI ${ }^{2}$}

${ }^{1}$ Firat University, Faculty of Education, Department of Social Studies Education, Turkey, ORCID: 0000-0003-2394-0049

2 Firat University, Department of Social Studies Education PhD Student, Turkey, ORCID: 0000-0003-0918-3715

To cite this article: Oner, U., \& Kinaci, M. K. (2020). The Views of Social Studies Teachers on Historical Empathy, International Online Journal of Educational Sciences, 12(3), 136-152

\begin{abstract}
ARTICLE INFO
Article History:

Received: 01.12.2019

Available online:

18.06.2020

ABSTRACT

The purpose of the study is to determine the views of Social Studies teachers about historical empathy. For this purpose, the views of the Social Studies teachers about the concept of historical empathy, the methods they applied and the problems experienced were tried to be determined. The study was conducted in accordance with the phenomenological design of the qualitative research. Study group of the research included 25 Social Studies teachers working in Malatya city center. The data of the study were obtained by using a semi-structured interview form with the interview technique and the obtained data were analyzed with the content analysis method. As a result of the study, it was determined that the teachers saw historical empathy as evaluation of events according to the conditions of the era and had knowledge about historical empathy. It was seen that teachers benefited from different methods and techniques to acquire this skill. In acquiring historical empathy skill, teachers were determined to experience problems arising from students, curricula, family and environment. For this reason, methods and techniques that are suitable for each student level and make the student active should be frequently included. In addition, while making regulations for the curriculum, teachers' views should be taken into consideration.
\end{abstract}

(C) 2020 IOJES. All rights reserved

Keywords:

Empathy, Social Studies Teaching, Historical empathy.

\section{Introduction}

Empathy is defined as a process that covers putting a person to another person's position and looking at the events from that person's perspective (Şeker, 2010, p. 91). Empathy is the process of not only understanding the feelings of a person while establishing a bond but also understanding the requests, thoughts, and opinions of that person (Karabağ, 2003, p. 31-32).

\footnotetext{
${ }^{1}$ Corresponding author's address: Firat University, Faculty of Education, Department of Social Studies Education Telephone: +902370000

Fax: 04242365064

e-mail: uoner@firat.edu.tr

DOI: https://doi.org/10.15345/iojes.2020.03.011
} 
Although empathy does not cover the entire history, it is also known as an intuitive view that enables the development of history and ensures to establish a connection with history (Yeager \& Foster, 2001, p. 17). Empathy requires thinking with evidence to understand history, allowing individuals to acquire some historical information, and using this information to explain events and institutions. A logical link established with history through empathy produces evidence-based ideas and these ideas show how views on historical conditions and goals are shaped even though they are considerably different from today's judgments (Lee \& Ashby, 2001, p. 25). Since empathy is against common ideas, it is a gain providing power outside of historical sense (Brooks, 2008, p. 130). Historical empathy is the ability to understand, perceive and explain events happened in the past through the views of people who have lived through history, depending on their beliefs and values (Y1lmaz, 2011, p. 29). At the end, historical empathy combines creative and logical thinking, which is associated with evidential and inferential skills that aim to fill the gap between known information and historical information (Yeager \& Foster, 2001, p. 15). Briefly, historical empathy is a logical and creative thinking ability that both provides access to historical information by using historical evidence and connects this information in the past with other possible results (Okur Berberoğlu, 2015b, p. 93-94).

Two dimensions of empathy, which is expressed as the process of understanding another person's feeling and thoughts correctly, are mentioned. These two dimensions are stated as cognitive and affective empathy (Coşkun Keskin, 2016, p.463). The affective and cognitive dimensions of historical empathy is important in terms of enabling people living in a fair society to establish their talents and values (Davison, 2013 , p. 41). Historical empathy will provide the individual with the ability to go beyond affective empathy and to establish a bond with historical characters and their experiences, as well as the ability to perceive the distance between these historical characters and the events (Bryant \& Clark, 2006, p. 1060). The fact that historical empathy has no affective dimension reduces the benefits improving human emotions but inability to control this affective dimension can arise with different problems such as sympathy or personal problems. Therefore, determining cognitive and affective limits of historical empathy can be educational (Endacott, 2014, p. 29). In fact, what matters here is to allow an individual to gain historical empathy skill that provide the opportunity to understand historical personalities without feeling sympathy or antipathy and to evaluate the historical events under the conditions of that period (Karabağ, 2003, p. 202). In short, it is necessary to determine cognitive and affective dimensions of historical empathy, to transfer them to the individuals and to allow historical empathy skills to develop in the individual.

Although historical empathy, which has an important function in understanding the past, is important for students to understand the history better, although it plays an important role in terms of historical questioning and it does not elicit all facts about the past (Yeager \& Foster, 2001, p. 18). Historical empathy requires focusing on that goal instead of reaching the goal (Davis, 2001, p. 3-4). In fact, what matters here is to understand the feelings of historical characters about the events and their thoughts and behaviors related to these feelings in historical empathy and most importantly is for students to know that historical characters do not reflect the same thoughts and views with today's perspective (Rantala, Manninen \& Van den Berg, 2016, p. 325).

Historical empathy is based on historical research methods requiring deduction as a result of the reasoning and the analysis of the obtained sources but these studies conducted with historical empathy include a study case that takes into account both the teacher and the students. While teachers form the study with the obtained resources and questions, they think about when and how they will use historical empathy (Endacott \& Brooks, 2013, p. 55). In fact, the development of historical empathy in students is an active process based on a historical method consisting of four interrelated stages (Yeager \& Foster, 2001, p. 14). Therefore, it is stated here that the student should be informed about the historical event first, that is, the students need to be informed about the historical subject for the development of historical empathy. Besides, a process is 
mentioned including understanding the relationship of historical events with each other and their chronology by the students, evaluating the evidences and interpretations of historical events and describing the obtained historical results.

It is likely that there are qualified classes with active participation and critical questioning and providing a learning environment in which the students are directed to do research for understanding the thoughts and behaviors of people in history and they are informed about historical empathy. This is a reason that necessitates the presence of historical empathy in the school environment (Foster, 2001, p. 178). The role of the teacher is very important in the development of the historical empathy skill. Therefore, besides the school, teacher's subject selection, the, and questions will be effective in the development of empathy in students (Okur Berberoğlu, 2015a, p. 219-220).

Historical empathy offers students different experiences so that they can live in a contemporary society by developing the student's perspective and the ability to interpret thoughts that are quite different from their own (Foster, 2001, p. 178). The Social Studies course aims to raise an effective citizen. The ability of these citizens to live together in the community depends on their understanding for other people, that is, their empathy skills (Aysal, 2012, p. 2). Therefore, Social Studies course is one of the courses that need mostly empathy skills by its nature because it is crucial for a student to have empathy skills and break the stereotypes by including his/her knowledge, feelings and thoughts (Coşkun Keskin, 2016, p. 464).

For this reason, some skills are included in the curriculum of Social Studies course and these skills are expected to be acquired by students. They are the teachers who will teach these skills to the students and train qualified individuals for the society. Therefore, teachers also need to have this knowledge and skills to train individuals who can adapt to changing societies (Ekinci \& Aybek, 2010, p. 818). In addition, historical empathy skill may not be suitable for development level of each student but guiding the students correctly with the use of appropriate tools-equipment and selection of appropriate method-technique is up to the teacher which only happens through teachers having this knowledge and skills.

Teachers, who play an effective role in the teaching and learning process, must constitute some prerequisites for teaching history subjects effectively through historical empathy (Y1lmaz, 2011, p. 29). Teachers generally apply activities towards the methods and techniques activating students and for increasing the interest in the course in order to teach historical subjects in this learning environment.

While many applications are made along with methods and techniques in teaching historical subjects in Social Studies course, historical empathy is one of these applications. It is known that the historical empathy technique used in teaching subjects related to the Social Studies course is effective in providing students with historical understanding and permanence (Aydın, 2016, p. 23-24). Although there are many benefits of using historical empathy in teaching historical events in Social Studies course, may be the most evident one is that it allows students to see the relationship of history with today and their own lives since it requires examining of the emotions, thoughts and perspectives of individuals who lived in the past. In this way, it helps to increase the students' interest towards Social Studies course which is considered as a memorization-based and thus boring course by breaking their prejudices (Aysal, 2012, p. 18).

Historical empathy is one of the important skills that should be taught to the students in the curriculum of Social Studies course. The aim of this study is to examine the views of the Social Studies teachers, who are the practitioner of the curriculum, about historical empathy. Therefore, interviews were conducted with Social Studies teachers and their views about the concept of historical empathy, the methods they use and the problems they experience were tried to be examined.

The main goal of this study is to determine the views of Social Studies teachers about historical empathy. In this regard, answers to the following questions were sought. 
1. How would you define historical empathy?

2. What is the importance of historical empathy in teaching Social Studies?

3. What are the methods and techniques you use while teaching historical empathy skills?

4. What are the problems you encounter while acquiring historical empathy skills?

5. What are your suggestions to teach historical empathy skill effectively?

\section{Method}

\section{Research Design}

The research was conducted in accordance with the phenomenological design. Phenomenology focuses on exploring how people express experience and transform experience into science as individual or shared meaning (Patton, 2000/2014, p. 104). In addition, phenomenological design focuses on known cases without a detailed and in-depth understanding. These cases can be events, perceptions, trends, experiences, concepts and various situations encountered every day in the world (Yıldırım \& Şimşek, 2016, p. 69).

\section{Study Group}

The study group of the research consists of 25 Social Studies teachers, 9 of whom are female and 16 of whom are male, working in Malatya city center during the fall semester of the 2019-2020 academic year. The study group was determined with easily accessible case sampling which is one of the purposeful sampling methods. Therefore, a non-probability purposeful sampling approach allows "in-depth research by selecting information rich situations depending on the goal of the study. It is preferred when it is intended to work in one or more special cases meeting certain criteria or having certain characteristics" (Büyüköztürk, Kılıç Çakmak, Akgün, Karadeniz \& Demirel, 2013, p. 90).

\section{Data Collection Tool}

The data in the study were collected with interview technique by using the semi-structured interview form. Semi-structured interviews combine both fixed choice answering and ability to go deeper in the field (Büyüköztürk, Kılıç Çakmak, Akgün, Karadeniz \& Demirel, 2013, p. 152). For this reason, the semi-structured interview form was used in the study. This form includes a list of questions and topics that will be discovered during the interview. Therefore, "interview form is prepared to get the same kind of information from different people by addressing similar issues. The interviewer can change the sentence structure of the questions and their order or go deeper in some topics during the interview. It provides time flexibility to the researcher. In such interviews, the interviewer has an outlined roadmap" (Avc1, 2008, p. 160).

In order to prepare the interview form of the study, literature review was made and the researches on the subject were investigated. The interview form was then finalized by the researcher obtaining the opinions of two faculty members from the Social Studies Education in Firat University Faculty of Education. In order to reach the goals determined in this study, the interview form consisting of 5 questions for Social Studies teachers developed by the researcher was used as the data collection tool. Before starting the interview, the sample group was informed about the research questions.

\section{Data Analysis}

Content analysis method was used to analyze the data obtained with the study. Content analysis is a scientific approach investigating the social reality through classifying objectively and systematically the message included in the verbal, written and other materials in terms of semantics and/or grammar perspective, transforming them into numbers and making inferences" (Tavşancıl \& Aslan, 2001, p. 22). 
Qualitative data analysis program was used to evaluate the data of the study (interviews). Data obtained from the interviews were transferred into the computer environment and prepared for the analysis. In order to facilitate the analysis of the statements in the interview, they were coded into short and meaningful symbols in accordance with the purpose of the study. While conducting analyses, the code list was prepared first and then these code lists were divided into themes to be consistent within themselves. The answers to the questions asked to the teachers were determined as the main themes and sub-themes based on the teachers' opinions for each question. Thus, it was found out how many teachers emphasized the same concept. These themes were then transformed into models in order to provide a clearer and more comprehensive view. These models were in turn interpreted and supported by quoting directly from the participants' opinions. Teachers' views about the themes and sub-themes are given in italics and quotes with the expressions formed with abbreviations such as (T.1.F/M), (teacher, 1. female/male).

As a result of the study, "reporting the collected data in details and explaining how the researcher reached the results in detail for ensuring the validity in a qualitative research" are among the criteria considered to be important (Yıldırım and Şimşek, 2016, p. 270). Therefore, in order to ensure the validity of the study results, themes obtained as a result of the study and reference sentences about these themes are included in the results section in detail by explaining how data analysis process, that is, themes were reached.

In order to ensure the reliability of the study, the opinion of the faculty member in the field of Social Studies Education of the Faculty of Education in Firat University was asked to confirm if the obtained theme and sub-themes represented the reference sentences. For this purpose, the themes and sub-themes were given to a faculty member who is an expert in his/her field for examination. The reliability of the study was calculated by comparing the matchings made by the expert and the themes previously made by the researcher and determining the number of consensus and disagreement in this respect. The reliability value calculated by the reliability formula of Miles and Huberman (1994/2016, p. 64) as "reliability = number of consensus/total consensus+number of disagreements" was found to be $90.16 \%$. According to Saban, "the desired reliability level in qualitative researches is provided in cases where the agreement between the expert and researcher's evaluations is $90 \%$ and above" (2009, p. 288).

\section{Findings}

Five main themes were identified for the views of Social Studies teachers on historical empathy. These themes were; "historical empathy", "the importance of historical empathy in teaching Social Studies", "methods and techniques used in teaching historical empathy", "problems encountered while teaching historical empathy" and "suggestions to acquire historical empathy".

\section{Opinions of Social Studies Teachers on the Definition of Historical Empathy}

One of the themes determined in accordance with the views of Social Studies teachers about the definition of historical empathy was about to what historical empathy is. The views of Social Studies teachers on the definition of historical empathy were obtained and it was determined as a result of these interviews that this theme had five sub-themes. Figure 1 shows the number of loading and model about this theme and sub-themes. 


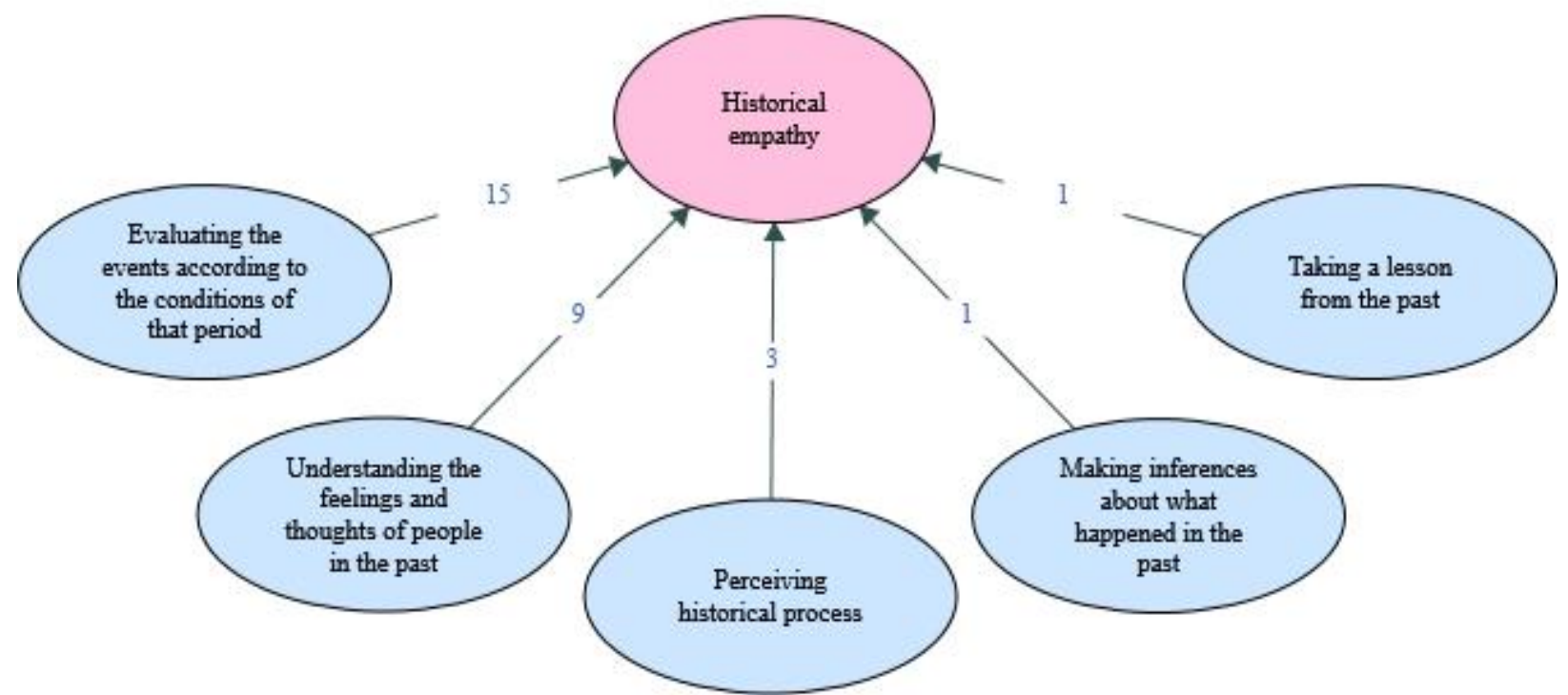

Figure 1. Model regarding the definition of historical empathy.

When the teacher's views about the definition of historical empathy were evaluated, the most intense loading was observed in the sub-theme of "evaluating events according to the conditions of that period". Other sub-themes determined for historical empathy were; "understanding the feelings and thoughts of people in the past" and "perceiving historical process". While "making inferences about what happened in the past" and "taking a lesson from the past" sub-themes were determined to be the least loaded sub-themes by teachers.

While one of the teachers who associated historical empathy theme with "evaluating the events according to the conditions of that period" sub-theme (T.4.F.) expressed as "the effort to perceiving historical process by considering the conditions of that period for an individual to understand the people who lived in the past." Another teacher (T.11.F.) stated historical empathy as "understanding and perceiving the feelings and thoughts of people, who lived in the past, according to the conditions of that period is called as historical empathy. Historical empathy is the evaluation of past under its conditions without using today's perspective. In short, it is the ability to understand the situation of people who lived in the past through their eyes." While another teacher (T.15.M.) explained his opinion as "it is the evaluation of past within its own conditions without using today's perspective and value judgments. It is to tell the past through the eyes of people who lived at that period." Another teacher (T.24.M.) was seen to express historical empathy as evaluating the historical events within the conditions of that period, far from today's conditions by stating that "In fact, historical empathy is to conduct an objective assessment by an historian away from cruelty considering the characteristics of the society such as psychology, economic structure, and power of managers in the conditions of that time by looking at the past with a very wide perspective."

\section{The Views of Social Studies Teachers about the Importance of Historical empathy in Social Studies Teaching}

The views of Social Studies teachers about the importance of historical empathy in Social Studies teaching were taken. When the teachers' views were evaluated, thirteen sub-themes related to the importance of historical empathy were determined. Figure 2 shows the number of loading and model related to this theme and subthemes. 


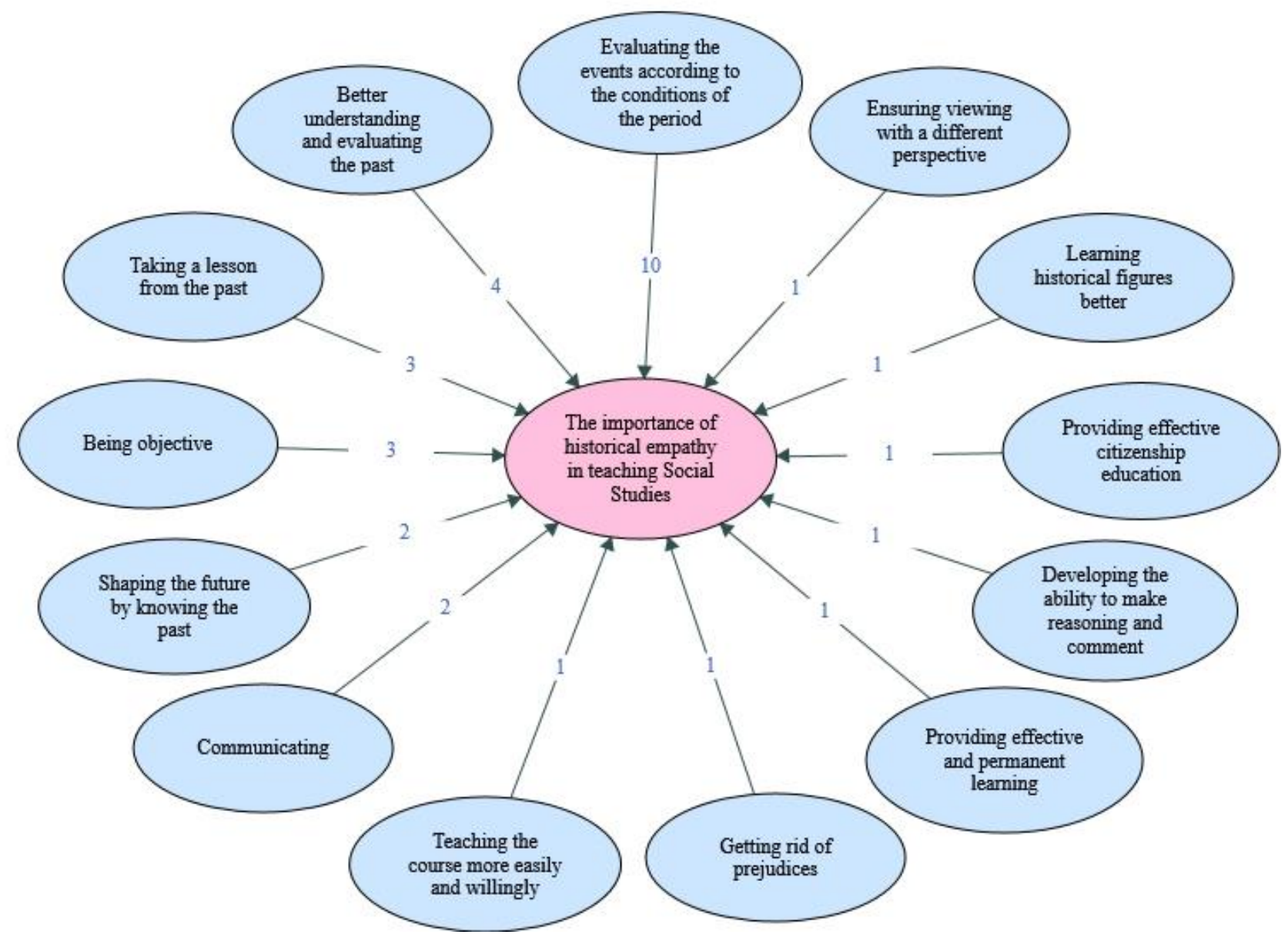

Figure 2. Model for the Importance of Historical Empathy in teaching Social Studies.

The highest amount of loading about the importance of historical empathy in teaching Social Studies was made for the subtheme of "evaluating the events according to the conditions of the period". The other sub-themes emphasized by the teachers were determined respectively as; "better understanding and evaluating the past", "taking a lesson from the past", "being objective", "shaping the future by knowing the past", and "communicating". Besides, the least loaded themes about the importance of historical empathy in teaching Social Studies were determined as "teaching the course more easily and willingly", "getting rid of prejudices", "providing effective and permanent learning", "developing the ability to make reasoning and comment", "providing effective citizenship education", "learning historical figures better", and "ensuring viewing with a different perspective".

One of the teachers (T.14.M.) who defined the importance of historical empathy in teaching Social Studies as "evaluating the events according to the conditions of the period" expressed his thoughts as "It is necessary for understanding the historical events with current judgments and criteria because it is important in terms of the appropriateness to the examination of each event with the conditions of its own period which is one of the most important conditions in the assessment of historical events." For his views about this sub-theme, another teacher (T.23.M.) explained his opinion about this subtheme as "...It is necessary to analyze well the conditions of the period where the events took place in order to interpret historical events. Otherwise, a correct interpretation cannot be reached. In a sense, historical empathy helps us to complete the process in the most correct way." Therefore, the teachers stated that they see historical empathy in teaching Social Studies as important in terms of providing the students with the opportunity to evaluate the historical events under the conditions of that period. 
One of the teachers (T.11.F.) expressing the importance of historical empathy in teaching Social Studies as "better understanding and evaluating the past" explained her opinion as "... Historical empathy helps to understand feelings, thoughts, and beliefs of the people in the past by putting us in their shoes. It provides understanding and evaluating the past by isolating from today's perspective." Another teacher (T.18.F.) expressed her opinion about this subtheme as "I think it is crucial. I believe it is important in order to make accurate assessment while teaching the students and perceive that period." In fact, the teachers stated that they saw historical empathy as important in teaching Social Studies in terms of comprehending and understanding the past.

The teachers associated the importance of historical empathy in teaching Social Studies with the "being objective" sub-theme. One of the teachers (T.8.F) expressed the importance of historical empathy in students in terms of providing objectivity with the sentence of "it is important for a better and impartial understanding of people in the past."

\section{The Views of Social Studies Teachers about the methods and techniques They use while Teaching Historical Empathy Skill}

Social Studies teachers' views about the methods and techniques used while teaching historical empathy skill were obtained. In accordance with the data obtained from these views, it was determined that there were fourteen sub-themes about the methods and techniques used while teaching historical empathy skill. Figure 3 shows model and the number of loading about this theme and subthemes.

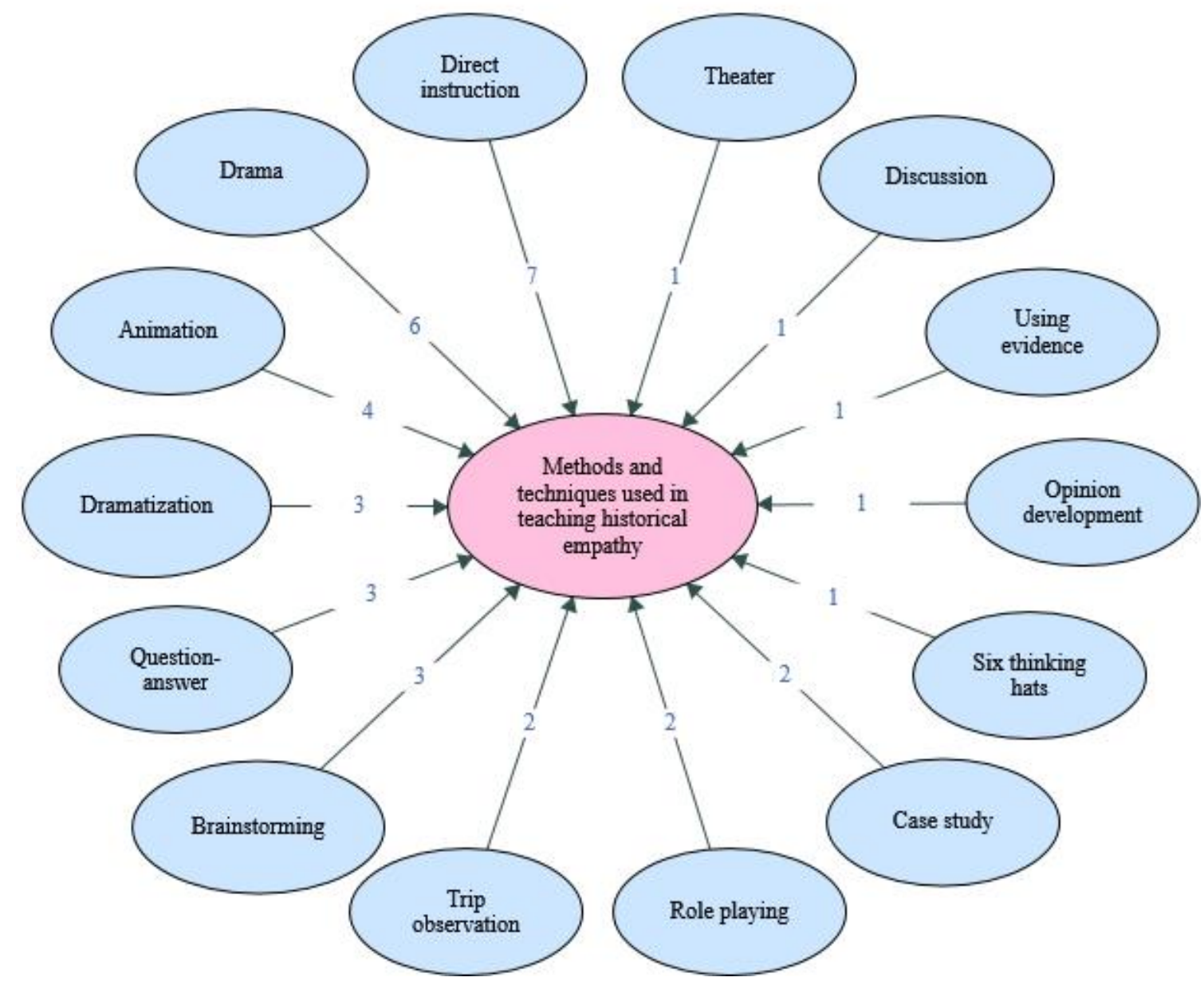

Figure 3. Model of methods and techniques used in teaching historical empathy. 
Social Studies teachers stated that they used many methods and techniques while teaching historical empathy skills. The teachers stated that they mostly used "direct instruction method" in teaching empathy skills and then the methods such as "drama", "animation", "dramatization", "question answer", "brainstorming", "trip observation", "role playing", "case study", "six thinking hats", "opinion development", "using evidence", "discussion" and "theater", respectively. Some sub-themes related to these data and the reference sentences of the teachers are given below.

A teacher (T.20.F.), expressing that the historical empathy can be acquired by associating the methods and techniques used while teaching historical empathy skill with "direct instruction" sub-theme, stated that knowledge is realized with direct instruction first and this is supported with different materials in order to realize historical empathy skill in students by stating that "while explaining the reasons of a war or a decision taken or a revolution made when I explain a historical event, I also make assessment by explaining the conditions of that period in a style that children can understand. I particularly try to use visual materials more, visual is more effective for perception especially after verbal explanation."

A teacher (T.3.F.) associating the methods and techniques used while teaching historical empathy skills with "drama" sub-theme stated the idea that "... I use drama technique. Especially in the $7^{\text {th }}$ grade students, a more accurate learning can be realized with this technique while teaching the subject of Ottoman Empire." Another teacher (T.2.M.) stated his opinion with "I use drama technique while teaching historical empathy skill..." Another teacher (T.11.F.) using drama method while teaching historical empathy mentioned that drama was effective on historical empathy skill in terms of learning historical personalities and historical events with fictional learning by saying that "In this course, we try to ensure that students revive the lives in the past and empathize with historical personalities through the drama method."

While a teacher (T.14.M), stating an opinion about "animation" sub-theme, expressed his opinion as "... I believe that students can interpret the historical characters and important events better by doing the animation." Another teacher (T.22.M.) said his thoughts about "role playing" sub-theme by stating that "I make them empathize with historical figures by using the role playing technique."

\section{The Views of Social Studies Teachers About Problems Encountered While Teaching Historical Empathy}

It was seen that Social Studies teachers stated that they had some problems while teaching historical empathy skill. Therefore, it was determined that there were fourteen subthemes related to this theme. Figure 4 shows model and number of loading for this theme and subthemes. 


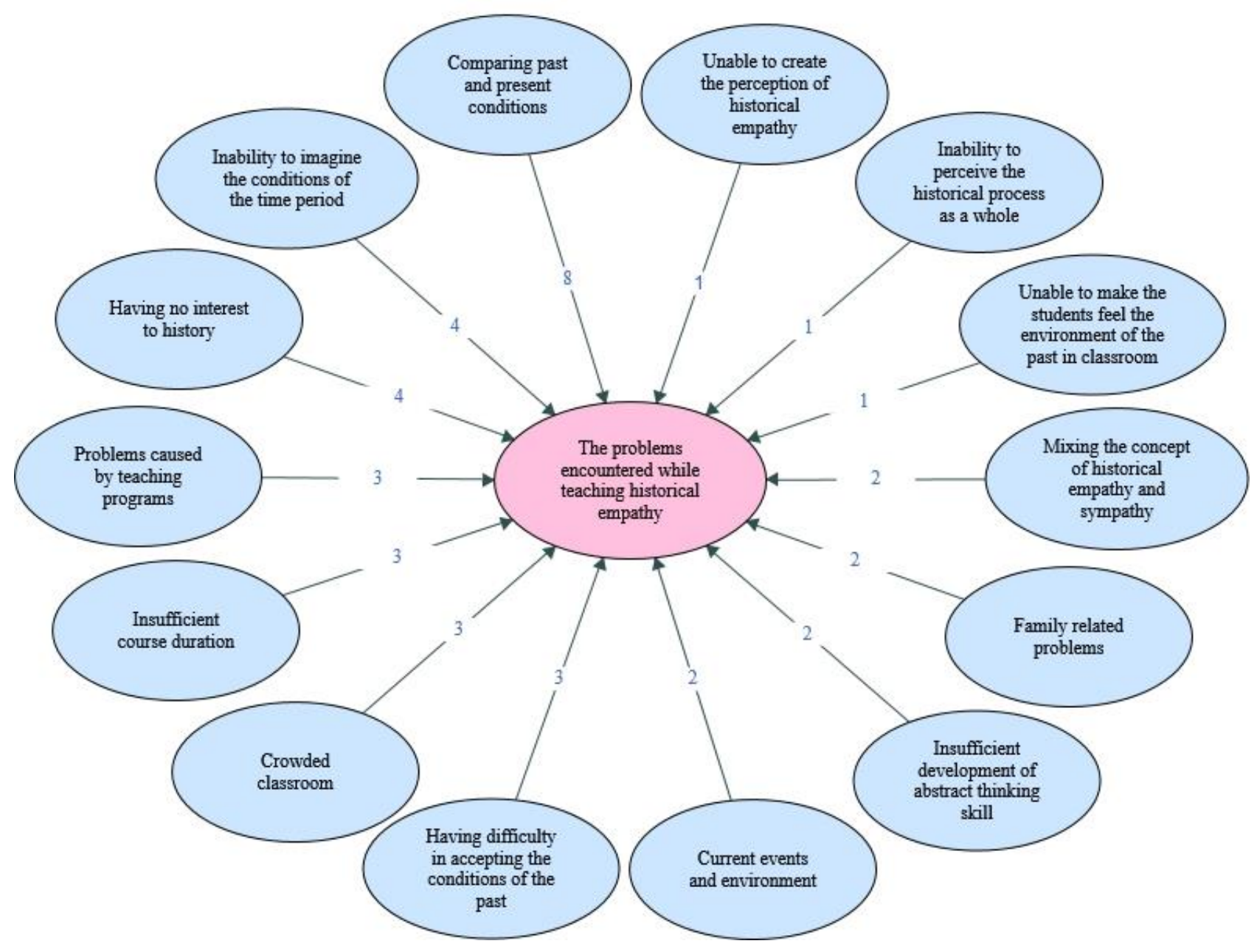

Figure 4. Model related to the problems encountered while teaching historical empathy.

Social Studies teachers stated that they had problems about "comparing the past and present conditions" while teaching historical empathy skill. The teachers stated that there are problems caused by the issues like "inability to imagine the conditions of the period", "having no interest to history", "problems caused by curricula", "insufficient lesson time", "crowded classroom", "having difficulty in accepting the conditions of the past ", "current events and environment", "insufficient development of abstract thinking skill", "family related problems", "confusing the concept of historical empathy with the concept of sympathy", "unable to make the students feel the environment of the past in classroom", "inability to perceive the historical process as a whole", and "unable to create the perception of historical empathy".

A teacher (T.11.F.), associating some problems experienced in teaching historical empathy skill with "comparing past and present conditions" sub-theme, stated that it is caused by the inability to understand the conditions of the past and to evaluate the past with today's conditions by saying that "Unfortunately, children cannot be bound by the conditions of the period. The students often make a comparison with the conditions of that period with the present conditions. It is also not easy for us to explain that the conditions of that time are different from today's conditions." Another teacher (T.3.F.) who believe the same things emphasized that the comparison made between the past and present conditions constituted an obstacle for the realization of historical empathy skill in the students by stating that "the students go for a comparison between the conditions of that period and present's conditions. This makes it difficult to establish empathy."

A teacher (T.24.M.), who stated his opinion with "inability to imagine the conditions of the period" subtheme, expressed that the students had problem caused by the inability to imagine the conditions of that 
period getting away from the today's world in order to do historical empathy by saying that "We see that our children have difficulty in imagining the conditions of that time period by leaving the technological society behind."

Another teacher (T.18.F.) expressing her opinions with "having no interest to history" sub-theme stated that there were problems caused by the students' lack of interest in history subjects and historical events in teaching this skill with the sentence of "The students are not interested in the events experienced in history and they do not pay full attention to historical issues..."

A teacher (T.14.M.) stating an opinion with "problems caused by curricula" sub-theme expressed that problems were experienced in teaching this skill due to the intense curriculum of Social Studies with the sentence of "It causes us to have difficulties in catching up the curriculum of Social Studies which is already intense during the course."

About "insufficient course duration" sub-theme, one of the teachers (T.2.M.) emphasized that there were problems due to limited time of the courses and it was hard to teach historical empathy skill within a limited period by saying that "the most important problem I have encountered is the short time. We cannot help students to acquire historical empathy skills sufficiently since we try to finish the subjects in 2 course hours per week."

A teacher (T.11.F.), who expressed an opinion about "crowded classroom" sub-theme, stated that it was not possible to get the opinions of every student due to the crowded classes and therefore there was a problem in teaching this skill in crowded classrooms by saying that "Classes are very crowded and it is not possible to get the opinions of each student separately or deal with them individually."

One of the teachers (T.12.M.) expressing his opinions about "having difficulty in accepting the conditions of the past" sub-theme emphasized that the historical events and the conditions at that period were very different from today's technology, they were having problems while transferring these information to the students and the students had difficulties in accepting this situation by stating that "I believe the greatest problem is to try to teach the events of that period to the individuals who never experienced the past, did not see and did not know the conditions of that period. In particular, there are major social, economic, political etc. differences between today's society shaped with technology and the past."

\section{Suggestions of Social Studies Teachers to Teach Historical Empathy}

In order to acquire historical empathy effectively, the recommendations of Social Studies teachers were obtained. In accordance with the opinions of the teachers evaluated, there were fourteen subthemes for this theme. Figure 5 shows the model and the number of loading for this theme and subthemes. 


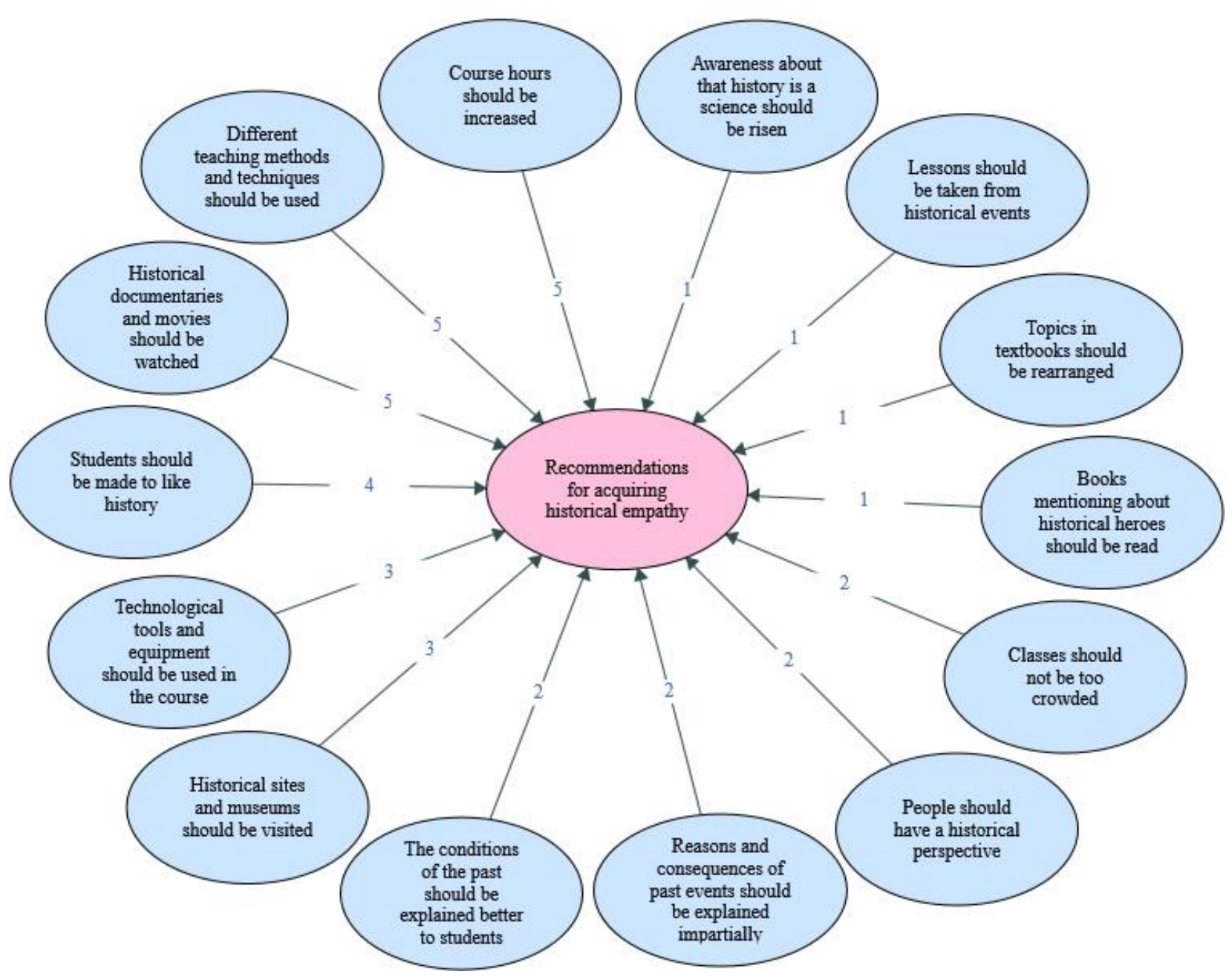

Figure 5. Model for recommendations for acquiring historical empathy.

It was determined that there were some problems in teaching historical empathy and the teachers had some recommendations for the solution of these problems. When the model related to recommendations about acquiring historical empathy effectively was examined, it was seen that "course hours should be increased", "different teaching methods and techniques should be used" and "historical documentaries and movies should be watched" sub-themes were the most loaded sub-themes by the Social Studies teachers. In addition, the teachers also recommended that "students should be made to like history", "technological tools and equipment should be used in the course", "historical sites and museums should be visited", "the conditions of the past should be explained better to students", "people should have a historical perspective", "classes should not be too crowded", "books mentioning about historical heroes should be read", "reasons and consequences of past events should be explained impartially", "topics in textbooks should be rearranged", "lessons must be taken from the history" and "awareness about that history is a science should be risen" in order to acquire historical empathy effectively.

About "course hours should be increased" subtheme, while one of the teachers (T.11.F.) recommended by saying that "as I said earlier, course hours should be increased in order for the students to acquire the historical empathy effectively"; whereas, another teacher (T.19.M.) stated the difficulties caused by limited course duration and emphasized that this problem should be solved by saying that "Historical empathy both makes history science to be loved and easy to learn. However, there is no enough time to use this method. We have to allocate very little time to this throughout the year because the Social Studies course is only 3 hours." 
A teacher (T.18.F.), who expressed her opinions about "different teaching methods and techniques should be used" sub-theme, expressed her opinion as "...Students should be made more eager about this subject by using different teaching methods and techniques", while another teacher (T.24.M.) emphasized that the use of different methods and techniques to acquire this skill was effective by stating that "Generally dramatized example (Having our students to be: M. Kemal, Fevzi Çakmak, M. Akif, Halide Edip and dramatize how they behave against the events and home defense)..."

One of the teachers (T.11.F.), who expressed her views about "historical documentaries and movies should be watched" sub-theme, stated her opinion as "the students can watch historical documentaries and movies ..." whereas, another teacher (T.18.F.) stated that showing series, movies or documentaries can be beneficial in terms of doing historical empathy by saying that "by showing historical movies, etc. the students can have empathy. For example, one of my students did not have much interest in the course first, I recommended the series of Dirilis Ertugrul. I realized that the student's interest in the course increased after watching the series."

\section{Conclusion, Discussion and Recommendations}

It was seen that the Social Studies teachers expressed historical empathy as "evaluating the events according to the conditions of the period". It was also determined that the teachers defined historical empathy as "understanding the feelings and thoughts of people in the past", "perceiving historical process", "making inferences about what happened in the past", and "taking a lesson from the past". Similarly, in their study Yllmaz and Koca (2012) examined perceptions, opinions, and experiences of history teachers on historical empathy and concluded that teachers expressed historical empathy as evaluating the historical events in their own conditions and perspective not today's perspective and also trying to understand the people in the past by using the emotions and thoughts of people in order to understand history and the events experienced in the past. In a study conducted by İslam (2019), it was concluded as a result of evaluating the knowledge and attitudes of History teachers that the teachers defined the historical empathy as evaluating the past in its own conditions, trying to understand how people thought and what they intended at those times, and assessing the lives, thoughts, activities of people in the past according to the understanding and conditions of that time and through their perspectives.

It was seen that the Social Studies teachers stated that with the historical empathy skill, the students could find the opportunity to "evaluate the historical events according to the conditions of that period". In addition, it has been found that historical empathy is important in terms of developments like "better understanding and evaluating the past", "taking a lesson from the past", "being objective", "shaping the future by knowing the past", "communicating", "teaching the course more easily and willingly", "getting rid of prejudices", providing effective and permanent learning", "developing the ability to make reasoning and comment", "providing effective citizenship education", "learning historical figures better" and "ensuring viewing with a different perspective". According to the information given by the teachers, it was believed that historical empathy in teaching Social Studies positively affected the development of the students and the Social Studies teaching. Similarly, it was stated in the study by Karabağ (2003) that historical empathy made students more curious about the course when the correct practices were made in the teaching of historical empathy. In the study of Yilmaz and Koca (2012), history teachers stated that historical empathy skill can contribute to students' self-development in many ways. In the study by İslam (2019), it was determined that the history teachers emphasized the importance of historical empathy skill in history course in terms of providing a different perspective, increasing permanence in the student's mind, thinking objectively, getting rid of prejudices of the past, understanding the past correctly and evaluating the historical events accurately, taking lessons from the historical events and taking examples from them, understanding the conditions of the past and evaluating the past under these conditions, that is, evaluating the events in the past with the perspective in that period but not today's conditions and drawing students' attention and focusing them on the course. 
It is seen that some concepts in the Social Studies course have abstract content and different methods and techniques are preferred by teachers to concretize these abstract concepts. Therefore, it was determined that the teachers utilized mostly different methods and techniques such as "direct instruction", "drama", "animation" and "dramatization" about the methods and techniques used while teaching historical empathy skill. In acquiring this skill, Social Studies teachers were also found to benefit from many different methods and techniques such as "question answer", "brainstorming", "role playing", "trip observation", "case study", "using evidence", "theater", "six thinking hats", "opinion development", and "discussion". Similarly, it was determined in the study by Karabağ (2003) that the students in the experimental group learnt by doing historical empathy with drama method, tried to understand the people in the past and their perspectives against events and showed improvement in this subject. In the study by Jensen (2008), it was investigated whether or not the use of discussion method by fifth grade students improved historical empathy skill and discussion and question answer methods were seen to be effective in gaining this skill and it would be beneficial to use historical discussions in fifth grade students in order to help them to gain historical empathy skills. It was concluded in the study by Aysal (2012) that some of the students found the history subjects in the Social Studies course boring and therefore, teaching Social Studies course with "role playing method based on historical empathy" will be more appropriate in terms of visualizing the events and facts in history and facilitating learning as well as understanding that the events and facts cannot be evaluated according to the present day. In their study, Yilmaz and Koca (2012) concluded that acting out historical figures by students, performing acting and drama, and placing themselves in the position of historical figures were seen to be historical empathy practice by history teachers. It was stated in the study by Savenije and Bruijn (2017) that trips to museums were important and necessary for supporting and developing the processes of historical empathy in students. In the study conducted by İslam (2019), some of the history teachers said that they made the students to do historical empathy by using question answer technique and acting out with drama. In the study by Güneş (2019), it was concluded that creative drama method was used to help students to gain historical empathy skill in Social Studies course and this method was found to be effective as a result of the evaluations.

The most important problem experienced by teachers while teaching historical empathy skills was "comparing past and present conditions". In acquiring this skill, the students were found to have problems such as "inability to imagine the conditions of the period", "having no interest to history", "having difficulty in accepting the conditions of the past", "insufficient development of abstract thinking skill", "inability to perceive the historical process as a whole", and "confusing the concepts of historical empathy and sympathy". It was also concluded that the teachers expressed that there were some problems caused by "the effect of current events and environment", "unable to create the perception of historical empathy", "unable to make the students feel the environment of the past in classroom", "insufficient course duration", "crowded classes", and "families and curricula". similarly, in their study, Yllmaz and Koca (2012) determined that the problems faced by history teachers in the process of applying historical empathy were that "some students had difficulty in understanding the conditions of the period of the events and had the tendency to investigate the historical events under today's conditions and their level was not sufficient to do empathy and there were also problems caused by the less class hours, parents and curriculum. In the study by Ata and Keçe (2014), Social Studies teachers stated that the reason behind why the students did not have historical empathy skill in a proper and correct way was that they could not reach abstract thinking and that historical empathy was considered as a concept knowledge rather than a skill in the curriculum which was caused by the wrong strategy followed in the learning-teaching process. In the study by İslam (2019), history teachers were determined to have problems in acquiring historical empathy about the situations such as the fact that students do not understand the course and enjoy the course since their empathy ability did not develop, they cannot think about the 
conditions of the past, that is, they did not comprehend the conditions of the past, they were not interested in the course, they could not think abstractly and also intense curriculum and insufficient course hours.

It was determined that there were some problems in the effective acquiring of historical empathy and the teachers had some recommendations for the solution of these problems. In order to acquire historical empathy effectively, the teachers had recommendations like it is necessary to "increase the course hour", "use of different teaching methods and techniques", "watch historical documentaries and movies" and "use of technological tools and materials in the class". It was also concluded that teachers made suggestions to gain this skill such as rearranging the subjects in the textbooks, taking lessons from historical events, gaining awareness that history is a science, getting people to have a historical perspective and explain the causes and consequences of the past events impartially. Similarly, in the study by Ata and Keçe (2014), it was stated that most of the Social Studies teachers did not use different teaching methods and techniques in the course, therefore they recommended that different methods and techniques that will make the students active such as creative drama, role playing should be focused more. In the study by İslam (2019), it was concluded that history teachers recommended for the solution of the problems they faced while teaching historical empathy skill that different techniques should be used in the class, students should be encouraged to read and research more, students should think and assess according to the conditions of the past, historical trips should be encouraged, course load should be decreased, class hours should be increased, students should have prior knowledge about historical events, visual materials should be increased (movies, photos, archive documents etc.) and the educational programs should be improved.

In accordance with the results of this study conducted to investigate the opinions of Social Studies teachers on historical empathy, some recommendations are given.

- In Social Studies course, trips to historical places and museums should be made by benefiting from historical photos, movies, documentaries and evidences in teaching history related subjects through historical empathy skill.

- In helping students to gain historical empathy skill, various visual materials suitable for each student level and the methods and techniques making the student active should be included frequently by considering their individual difference and development levels.

- In having students acquire the concepts containing cognitive processes such as historical empathy skill, intense curriculum of Social Studies, insufficient course duration and inability to deal with each student due to some crowded classes are among the problems experienced. For this reason, while preparing the curriculum, arrangements can be made regarding the duration of the course, the intensity of the course content and also the crowded classes that still pose problems by considering the opinions of teachers.

- Studies examining the teacher and student together for gaining historical empathy skill in teaching Social Studies can be conducted. 


\section{REFERENCES}

Ata, B. ve Keçe, M. (2014). Öğrencilerin tarih okuryazarlığı düzeylerini etkileyen faktörler: öğretmen görüşlerine dayalı nitel bir araştırma. Türk Tarih Eğitimi Dergisi, 3(2), 1-23.

Avcı, M. (2008). Bilimsel araştırmalarda veri toplama. O. Kılıç ve M. Cinoğlu (Ed), Bilimsel araştırma yöntemleri içinde (s.145-170). İstanbul: Lisans Yayınc1lı.

Aydın, M. (2016). Tarihsel empatiyle sosyal bilgiler öğretimi. R. Sever, M. Aydın ve E. Koçoğlu (Ed). Alternatif yaklaşımlarla sosyal bilgiler eğitimi içinde (s. 15-27). Ankara: Pegem Akademi.

Aysal, A. (2012). İlköğretim 7. sinff sosyal bilgiler dersinde tarihsel empatiye dayal rol oynama yönteminin akademik başarıya etkisi. Yayımlanmamış yüksek lisans tezi, Afyon Kocatepe Üniversitesi Sosyal Bilimler Enstitüsü, Afyonkarahisar.

Brooks, S. (2008). Displaying historical empathy: what impact can a writing assignment have. Social Studies Research and Practice, 3(2), 130-146.

Bryant, D. \& Clark, P. (2006). Historical empathy and canada: a people's history. Canadian Journal of Education, 29(4), 1039-1064.

Büyüköztürk, Ş., Kılıç Çakmak, E., Akgün, Ö. E., Karadeniz, Ş. ve Demirel, F. (2013). Bilimsel araştırma yöntemleri. Ankara: Pegem Akademi.

Coşkun Keskin, S. (2016). Empatik düşünme becerisi. D. Dilek (Ed), Sosyal bilgiler eğitimi içinde (s. 445-464). Ankara: Pegem Akademi.

Davis Jr, O. L. (2001). In pursuit of historical empathy. In O. L. Davis Jr., E. A. Yeager, \& S. J. Foster (Eds), Historical empathy and perspective taking in the social studies (pp. 1-12). New York, NY: Rowman and Littlefield Publishers Inc.

Davison, M. C. (2013). It is really hard being in their shoes: developing historical empathy in secondary school students. Unpublished doctorate dissertation, The University of Auckland, New Zealand.

Ekinci, Ö. ve Aybek, B. (2010). Öğretmen adaylarının empatik ve eleştirel düşünme eğilimlerinin incelenmesi. İlköğretim Online, 9(2), 816-827.

Endacott, J. L. \& Brooks, S. (2013). An updated theoretical and practical model for promoting historical empathy. Social Studies Research and Practice, 8(1), 41-58.

Endacott, J. L. (2014). Negotiating the process of historical empathy. Theory and Research in Social Education, 42(1), 4-34.

Foster, S. J. (2001). Historical empathy in theory and practice: some final thoughts. In O. L. Davis Jr., E. A. Yeager \& S. J. Foster (Eds), Historical empathy and perspective taking in the social studies (pp. 167-181). New York, NY: Rowman and Littlefield Publishers Inc.

Güneş, S. (2019). Sosyal bilgiler dersinde yaratıcı drama yöntemiyle tarihsel empati becerisinin kazandırılmasına yönelik etkinlik temelli bir eylem araştırması. Yayımlanmamış yüksek lisans tezi, Bartın Üniversitesi Eğitim Bilimleri Enstitüsü, Bartın.

İslam, İ. T. (2019). Tarih öğretmenlerinin tarihsel empatiyle ilgili bilgi ve tutumlarının değerlendirilmesi. Yayımlanmamış yüksek lisans tezi, Trabzon Üniversitesi Lisansüstü Eğitim Enstitüsü, Trabzon.

Jensen, J. (2008). Developing historical empathy through debate: an action research study. Social Studies Research and Practice, 3(1), 55-67. 
Karabağ, Ş. G. (2003). Öğretilebilir ve bilişsel bir beceri olarak tarihi empati. Yayımlanmamış doktora tezi, Gazi Üniversitesi Eğitim Bilimleri Enstitüsü, Ankara.

Lee, P. \& Ashby, R. (2001). Empathy, perspective taking, and rational understanding. In O. L. Davis Jr., E. A. Yeager, \& S. J. Foster (Eds), Historical empathy and perspective taking in the social studies (pp. 21 -50). New York, NY: Rowman and Littlefield Publishers Inc.

Miles, M. B. ve Huberman, A. M. (2016), Analizde ilk adımlar, A. Ersoy (Çev.). S. Akbaba Altun ve A. Ersoy (Çev. Ed.), Genişletilmiş bir kaynak kitap: Nitel veri analizi içinde (s. 50-88). 1994, Ankara: Pegem Akademi.

Okur Berberoğlu, E. (2015a). Historical empathy and perspective taking in the social studies. Turkish History Education Journal, 4(1), 216-226.

Okur Berberoğlu, E. (2015b). Kitap incelemesi: sosyal bilimlerde tarihsel empati ve bakış açısı kazanma. Balıkesir Üniversitesi Sosyal Bilimler Enstitüsü Dergisi, 18(33), 93-96.

Patton, M. Q. (2014). Nitel araştırmada çeşitlilik: Kuramsal yönelimler, E. Bukova Güzel ve H. Demircioğlu (Çev.). M. Bütün ve S. B. Demir (Çev. Ed.), Nitel araştırma ve değerlendirme yöntemleri içinde (s. 75-142). 2000, Ankara: Pegem Akademi.

Rantala, J., Manninen, M. \& Van den Berg, M. (2016). Stepping into other people's shoes proves to be a difficult task for high school students: assessing historical empathy through simulation exercise. Journal of Curriculum Studies, 48(3), 323-345.

Saban, A. (2009). Öğretmen adaylarının öğrenci kavramına ilişkin sahip oldukları zihinsel imgeler. Türk Ĕ̆gitim Bilimleri Dergisi, 7(2), 281-326.

Savenije, G. M. \& de Bruijn, P. (2017). Historical empathy in a museum: uniting contextualisation and emotional engagement. International Journal of Heritage Studies, 23(9), 832-845.

Şeker, K. (2010). Tarih ve sosyal bilgiler öğretiminde empati. Mehmet Akif Ersoy Üniversitesi Sosyal Bilimler Enstitüsü Dergisi, 2(2), 91-105.

Tavşancıl, E. ve Aslan, E. (2001). Sözel, yazılı ve diğer materyaller için içerik analizi ve uygulama örnekleri. İstanbul: Epsilon Yayıncilık.

Yeager, E. A. \& Foster, S. I, (2001). The role of empathy in the development of historical understanding. In O. L. Davis Jr., E. A. Yeager, \& S. J. Foster (Eds), Historical empathy and perspective taking in the social studies (pp. 13-20). New York, NY: Rowman and Littlefield Publishers Inc.

Yıldırım, A. ve Şimşek, H. (2016). Sosyal bilimlerde nitel araştırma yöntemleri. Ankara: Seçkin Yayıncılık.

Yılmaz, K. ve Koca, F. (2012). Tarihsel empati üzerine nitel bir araştırma: tarih öğretmenlerinin algı, görüş ve deneyimlerinin incelenmesi. Gaziantep Üniversitesi Sosyal Bilimler Dergisi, 11(3), 855-879.

Yılmaz, K. (2011). Sosyal bilgiler ve tarih öğretiminde tarihsel empati: geçmişe geçmişteki insanların gözüyle bakabilme becerisi. R. Turan, A. M. Sünbül \& H. Akdağ (Ed). Sosyal bilgiler öğretiminde yeni yaklaşımlar2 içinde (s. 12-30). Ankara: Pegem Akademi. 